\title{
Trichomes micromorphology and essential oil variation at different developmental stages of cultivated and wild growing Mentha pulegium $\mathrm{L}$. populations from Portugal
}

\author{
Leandra Rodrigues ${ }^{\mathrm{a}, *}$, Orlanda Póvoa ${ }^{\mathrm{b}}$, Generosa Teixeira $^{\mathrm{c}}$, Ana Cristina Figueiredo ${ }^{\mathrm{d}}$, \\ Margarida Moldão ${ }^{a}$, Ana Monteiro ${ }^{a}$ \\ a Centro de Botânica Aplicada à Agricultura (CBAA), Instituto Superior de Agronomia, Thecnical University of Lisbon, Tapada da Ajuda, 1349-017 Lisboa, Portugal \\ ${ }^{\mathrm{b}}$ Escola Superior Agrária de Elvas, Edifício do Trem Auto, Avenida 14 de Janeiro, 7350-903 Elvas, Portugal \\ c Universidade de Lisboa, Faculdade de Farmácia de Lisboa, Centro de Biologia Ambiental, Av. Prof. Gama Pinto, 1649-003 Lisboa, Portugal

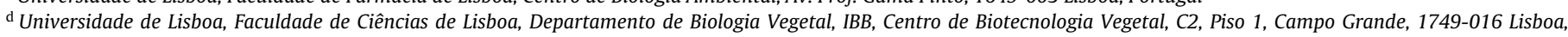 \\ Portugal
}

\section{A R T I C L E I N F O}

\section{Article history:}

Received 11 April 2012

Received in revised form 11 July 2012

Accepted 31 July 2012

\section{Keywords:}

Mentha pulegium $\mathrm{L}$.

Lamiaceae

Trichomes

Essential oil

Histochemistry

GC

GC-MS

\begin{abstract}
A B S T R A C T
The indumentum of Mentha pulegium L., studied by light and scanning electron microscopy, was characterized by non-glandular and glandular trichomes, which corresponded to the common arrangement described for the Lamiaceae family. Histochemistry revealed the presence of pectins, total lipids, acidic lipids and essential oils in the glandular trichomes secretions. The essential oil yield ranged from $0.3 \%$ (w/d.w.) in the vegetative phase to $1.6 \%$ at full flowering. Gas chromatography and gas chromatography-mass spectrometry essential oils composition analysis at full flowering revealed mostly quantitative rather than qualitative variations, with pulegone as the major compound (52-82\%), followed by isomenthone (2-36\%), menthone (0.1-17\%), and piperitenone (1-15\%). Comparative evaluation of cultivated and wild growing populations showed differences in the relative amounts of the main components of the essential oils isolated from plants harvested at different developmental stages.
\end{abstract}

(C) 2012 Elsevier B.V. All rights reserved.

\section{Introduction}

The genus Mentha L. (Lamiaceae), comprising more than 25 species, is responsible for approximately $2000 \mathrm{t}$ of world essential oil, making it the second most important essential oil producing genus, after Citrus (Mucciarelli et al., 2001). Mentha pulegium L., a member of this genus, commonly known as pennyroyal (poejo in Portuguese), is an aromatic perennial herbaceous plant reaching up to $40 \mathrm{~cm}$ height (Stengele and Stahl-Biskup, 1993). This species grows wild in humid and damp areas and water banks of central, southern and Western Europe, north Africa and Asia Minor (Chalchat et al., 2000; Tutin et al., 1972). The aerial parts are pubescent bearing glandular trichomes which are responsible for the essential oil secretion. The morphology,

\footnotetext{
* Corresponding author at: DCEB/Secção de Herbologia, Instituto Superior de Agronomia, Technical University of Lisbon, Tapada da Ajuda, 1349-017 Lisboa, Portugal. Fax: +351 213653238.

E-mail addresses: liarodrigues@isa.utl.pt, leandra_rodrigues@hotmail.com (L. Rodrigues).
}

distribution and frequency of these glandular trichomes are distinctive characteristics among the Lamiaceae species (Werker, 2000). In Portugal, the aerial parts of M. pulegium and the preparations from it have been traditionally used in Alentejo Region to flavour recipes, as well as for its medicinal properties (Póvoa et al., 2006). In folk medicine it is used as an infusion, preventing different gastric disorders and inflammations of the respiratory tract (Mkaddem et al., 2007; Póvoa et al., 2006). Nevertheless, there are no approved medicinal uses for pennyroyal essential oil (Barceloux, 2008). This plant has also been used as a spice and flavouring agent in different foods (Mkaddem et al., 2007; Monteiro et al., 2007a), despite de fact that the essential oils of M. pulegium are generally considered to be rich in pulegone, a toxic compound with potentially lethal hepatotoxic effects (Anderson et al., 1996). Several publications, reports and directives of the UE emphasize the need for a better characterization of botanicals and botanical preparations and for scientific assessment of risks from exposure of consumers to these products. The UE directive 88/388/EEC has stipulated a maximum concentration for this oxygen-containing monoterpene of $100 \mathrm{mg} / \mathrm{kg}$ in beverages and $25 \mathrm{mg} / \mathrm{kg}$ in foodstuff, with the exception of $250 \mathrm{mg} / \mathrm{kg}$ in 
flavoured beverages and $350 \mathrm{mg} / \mathrm{kg}$ in mint confectionery (EEC, 1988).

It is known that the chemical composition of plants is influenced by several external factors including growing conditions and climate (Figueiredo et al., 2008). The essential oils from M. pulegium have been characterized in different regions of the world, Table 1 (and references therein). Despite these reports, and studies in Portuguese cultivated populations (Lopes et al., 2010; Monteiro et al., 2007b; Teixeira et al., 2012), there is no previous report on the chemical composition of wild growing populations of $M$. pulegium volatile oils from mainland Portugal. One should not forget that, in cultivated mint plants the qualitative oil composition is relatively stable, but in most wild growing mints a great diversity in essential oil constituents has been observed (Mimica-Dukic and Bozin, 2008).

In view of the potential pharmacological, commercial and food industry value of this species, the work described in this paper was carried out to (1) characterize, by light and scanning electron microscopy, the morphology and structure of the indumentum, in particular of the glandular trichomes, which are the main responsible for the essential oils secretion, (2) typify the chemical composition of the essential oil from Portuguese M. pulegium wild populations, (3) compare the essential oil composition between cultivated and wild growing populations and (4) evaluate the evolution of the essential oil components throughout the plant developmental stages.

\section{Material and methods}

\subsection{Plant material}

In 2009, several field trips were conducted across the geographic range of $M$. pulegium. A total of 14 populations with different geographic origins, representative of the distribution of the species in mainland Portugal, were included in the analysis (Table 2, Fig. 1). To characterize the essential oil (EO) composition and identify possible chemotypes, these 14 populations were collected, during the flowering phase, from natural habitats. Voucher specimens have been deposited in the LISI herbarium (Table 2).

In order to understand the evolution in EO composition and yield along the plant life cycle, and compare cultivated with wild growing conditions, a time-course study was undertaken. In this study, six populations ( 15 plants per population) where collected from the wild, transported in containers and transplanted to the essay field at Instituto Superior de Agronomia, Lisbon, Portugal. Plants were planted $50 \mathrm{~cm}$ apart, in $2 \mathrm{~m}^{2}$ plots, and drip irrigated periodically (each 7-10 days). Plots were kept weed free by hand hoeing. Samples from the six populations, in the wild and in the cultivated essay field, were harvested at the vegetative, pre-flowering and full flowering phases.

\subsection{Morphological studies}

\subsubsection{Light microscopy (LM)}

Stems, leaves and flowers at the different developmental stages, of 10 individuals for each population, were fixed with $3 \%$ glutaraldehyde (Merck, Germany) in a $0.1 \mathrm{M}$ sodium phosphate buffer,

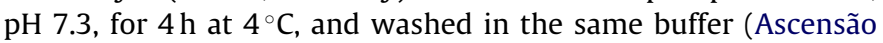
et al., 1999). After dehydration in a graded series of ethanol solutions, hand-cut cross-sections were made and clarified with sodium hypochlorite and washed in distilled water (Evans, 1996). Observations were carried out under a Nikon Eclipse E400 microscope equipped with a Nikon Coolpix MDC lens adapter. Images were obtained with a Nikon Coolpix 995 digital camera. Quantitative

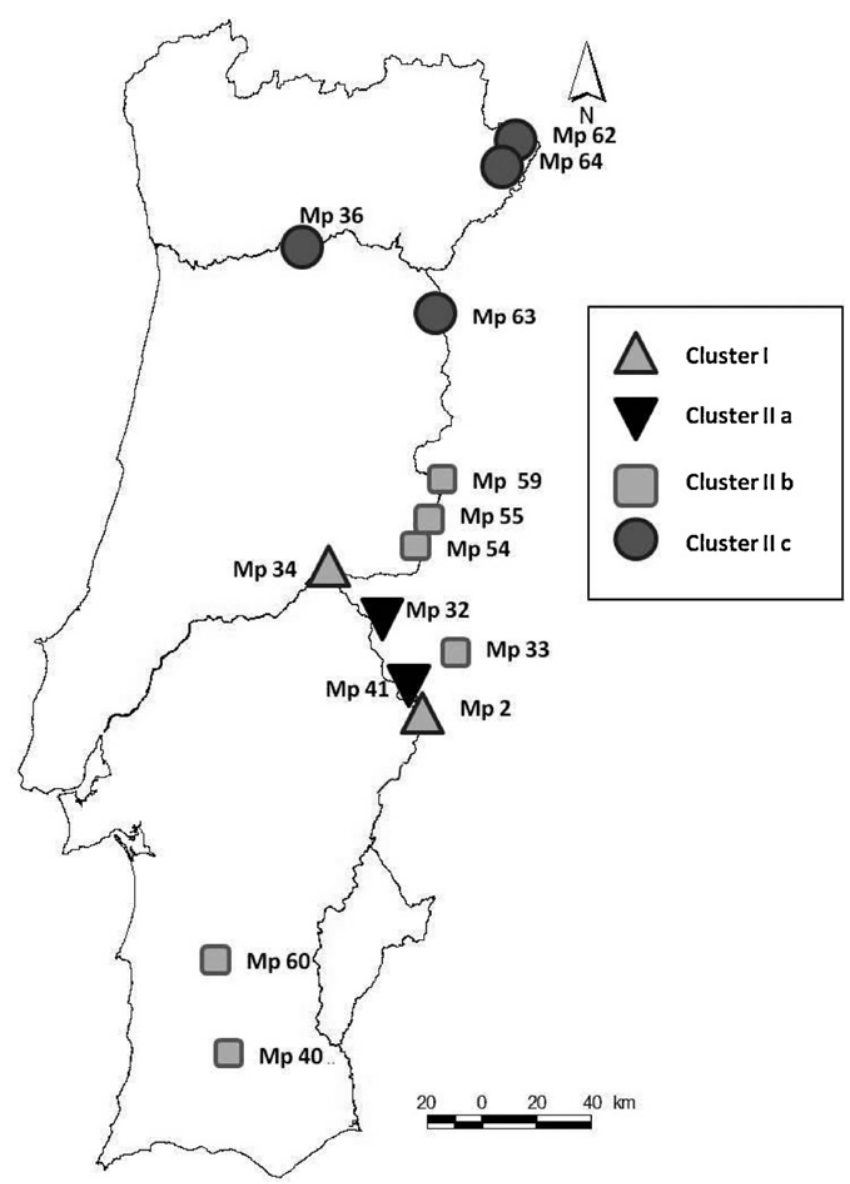

Fig. 1. Map of Portugal with collection sites of Mentha pulegium populations analyzed. Symbols, according to the essential oil cluster analysis (Fig. 3). For abbreviations, see Table 2 .

characters are the average of, at least, 30 different observations for each population.

\subsubsection{Scanning electron microscopy (SEM)}

Plant material was fixed as above, critical-point dried in a Polaron BioRad E3500, and coated with gold in a Jeol JFC-1200 (Tokyo, Japan). Observations were carried out at $15 \mathrm{kV}$, on a Jeol JSM-5220 LV scanning electron microscope (Tokyo, Japan) equipped with an image acquisition system. Measures and counting were obtained by computer-assisted image analysis.

\subsection{Histochemical studies}

General staining procedures for detecting some of the main chemical groups secreted were carried out using fresh leaves and flowers from 2 populations (Table 1). The histochemical tests included: (1) Sudan III for total lipids (Johansen, 1940); (2) Nile Blue for neutral and acidic lipids (Jensen, 1962); (3) Nadi reagent for essential oils and resin acids (David and Carde, 1964); and (4) Ruthenium Red for pectins (Johansen, 1940). Standard control procedures were carried out simultaneously.

\subsection{Essential oil analysis}

\subsubsection{Isolation procedure}

For each sample, aerial parts of 10 individuals per population were collected, grossly pulverized, and $20 \mathrm{~g}$ were subjected to hydrodistillation for $1 \mathrm{~h}$ in a Clevenger-type apparatus according 
Table 1

Data from previous studies on the essential oil composition of Mentha pulegium L.

\begin{tabular}{|c|c|c|c|c|c|}
\hline Collection country & Plant part & Extraction procedure & Main component(s) (\%) & Identification method & Reference \\
\hline Algeria & Aerial parts & Hydrodistillation & Pulegone 4-87 & GC, GC/MS & Beghidja et al. (2007) \\
\hline Bulgaria & Aerial parts & $\begin{array}{l}\text { Water and steam } \\
\text { distillation }\end{array}$ & Pulegone 43-45 & GC, GC/MS & Stoyanova et al. (2005) \\
\hline European countries & $\begin{array}{l}\text { Different plant } \\
\text { parts }\end{array}$ & Hydrodistillation & Pulegone 7-85 & GC, GC/MS & Stengele and Stahl-Biskup (1993) \\
\hline Greece & Aerial parts & Hydrodistillation & Pulegone 0.1-91 & GC, GC/MS & Kokkini et al. (2004) \\
\hline India & Aerial parts & Hydrodistillation & Pulegone 65-83 & $\begin{array}{l}\text { GC, GC/MS. }{ }^{1} \mathrm{H} \text { NMR, } \\
{ }^{13} \mathrm{C} \text { NMR }\end{array}$ & Agnihotri et al. (2005) \\
\hline Iran & Aerial parts & Hydrodistillation & Pulegone 38 & GC/MS & Aghel et al. (2004) \\
\hline Iran & Aerial parts & Hydrodistillation & $\begin{array}{l}\text { Piperitone } 38 \\
\text { Piperitenone } 33\end{array}$ & GC, GC/MS & Mahboubi and Haghi (2008) \\
\hline Iran & Aerial parts & Hydrodistillation & Menthone 39 & GC, GC/MS & Hassanpouraghdam et al. (2011) \\
\hline Portugal & Aerial parts & Hydrodistillation & Pulegone 60 & GC, GC/MS & Monteiro et al. (2007b) \\
\hline Portugal & Aerial parts & Hydrodistillation & Pulegone 65-87 & GC, GC/MS & Lopes et al. (2010) \\
\hline Portugal & Aerial parts & Hydrodistillation & $\begin{array}{l}\text { Menthone } 36 \text { Pulegone } \\
23\end{array}$ & GC, GC/MS & Teixeira et al. (2012) \\
\hline Portugal & Aerial parts & Hydrodistillation & $\begin{array}{l}\text { Pulegone } 35 \\
\text { Piperitenone } 27\end{array}$ & GC/MS & Mata et al. (2007) \\
\hline Portugal & Aerial parts & Hydrodistillation & Pulegone 80 & GC, GC/MS & Reis-Vasco et al. (1999) \\
\hline Spain & Aerial parts & Hydrodistillation & Pulegone 41-42 & GC, GC/MS, & Maroto-Diaz et al. (2007) \\
\hline Tunisia & Aerial parts & Hexane extract & Pulegone 42 & GC, GC/MS & Mkaddem et al. (2007) \\
\hline Tunisia & Aerial parts & Hydrodistillation & Pulegone 44 & GC, GC/MS & Hajlaoui et al. (2010) \\
\hline Turkey & Aerial parts & Hydrodistillation & Pulegone 72 & GC, GC/MS & Sarikurkcu et al. (2012) \\
\hline Uruguay & Leaves & Hydrodistillation & Pulegone 73 & GC-FID, GC/MS & Lorenzo et al. (2002) \\
\hline Yugoslavia & Aerial parts & Steam Distillation & Menthone 31 & GC, GC/MS & Chalchat et al. (2000) \\
\hline
\end{tabular}

to the European Pharmacopoeia (Council of Europe, 2007). The oils were kept at $4{ }^{\circ} \mathrm{C}$ until further analysis.

\subsubsection{Gas chromatography (GC)}

GC analysis were performed using a PerkinElmer 8700 gas chromatograph (PerkinElmer, Shelton, CT, USA) equipped with two FIDs, a data-handling system, and a vaporizing injector port in which two columns of different polarities were installed: a DB-1 fused-silica column $(30 \mathrm{~m} \times 0.25 \mathrm{~mm}$ i.d., film thickness $0.25 \mu \mathrm{m}$; J \& W Scientific Inc., Agilent Technologies, Santa Clara, CA, USA); and a DB-17HT fused-silica column $(30 \mathrm{~m} \times 0.25 \mathrm{~mm}$ i.d., film thickness $0.15 \mu \mathrm{m}$; J \& W Scientific Inc.). Oven temperature was programmed, $45-175^{\circ} \mathrm{C}$, at $3^{\circ} \mathrm{C} \mathrm{min}^{-1}$, subsequently at $15^{\circ} \mathrm{C} \mathrm{min}^{-1}$ up to $300^{\circ} \mathrm{C}$, and then held isothermal for $10 \mathrm{~min}$; injector and detector temperatures were $280^{\circ} \mathrm{C}$ and $290^{\circ} \mathrm{C}$, respectively; carrier gas, hydrogen, adjusted to a linear velocity of $30 \mathrm{~cm} \mathrm{~s}^{-1}$. Samples were injected using the split sampling technique, ratio $1: 50$, with a volume of injection of $0.1 \mu \mathrm{l}$ of a pentane-oil solution. The percentage composition of the oils was computed by the normalization method from the GC peak areas, which were calculated as mean values of two injections of each oil sample, without using response factors.

\subsubsection{Gas chromatography-mass spectrometry (GC-MS)}

The GC-MS unit consisted of on PerkinElmer Autosystem XL gas chromatograph (PerkinElmer, Shelton, Connecticut, USA), equipped with DB- 1 fused-silica column $(30 \mathrm{~m} \times 0.25 \mathrm{~mm}$ i.d., film thickness $0.25 \mu \mathrm{m}$; J \& W Scientific, Inc., Agilent Technologies, Santa Clara, CA, USA), and interfaced with a PerkinElmer Turbomass mass spectrometer (software version 4.1, PerkinElmer, Shelton, CT, USA). Injector and oven temperatures were as above; transfer line temperature, $280^{\circ} \mathrm{C}$; ion trap temperature, $220^{\circ} \mathrm{C}$; carrier gas, helium, adjusted to a linear velocity of $30 \mathrm{~cm} \mathrm{~s}^{-1}$; split ratio, 1:40; ionization energy, $70 \mathrm{eV}$; ionization current, $60 \mu \mathrm{A}$; scan range, 40-300 $\mu \mathrm{m}$; scan time, $1 \mathrm{~s}$. The identity of the components was assigned by comparison of their retention indices, relative to a $\mathrm{C}_{9}-\mathrm{C}_{17}$ hydrocarbon standard mixture, and with GC-MS spectra from a home-made library, constructed based on the analyses of reference oils, laboratory-synthesised components and commercial available standards.

\subsubsection{Data analysis}

The percentage composition of the isolated essential oils was used to determine the relationship between the different samples

Table 2

Data on collection site and sample type of Mentha pulegium wild populations studied.

\begin{tabular}{|c|c|c|c|c|c|c|c|}
\hline \multirow[t]{2}{*}{ Populations } & \multirow[t]{2}{*}{ Sample type ${ }^{a}$} & \multicolumn{6}{|l|}{ Specific sample collection sites } \\
\hline & & Localization & Altitude (m) & Latitude & Longitude & Hidrografic basin & Voucher \\
\hline Mp2 & $\mathrm{W} / \mathrm{C} / \mathrm{DS}$ & Ouguela, Campo Maior & 207 & $39^{\circ} 4^{\prime} 54.96^{\prime \prime} \mathrm{N}$ & $7^{\circ} 0^{\prime} 4.33^{\prime \prime} \mathrm{W}$ & Guadiana & $1059 / 2010$ \\
\hline Mp32 & $\mathrm{W} / \mathrm{C} / \mathrm{DS}$ & Valência de Alcântara & 313 & $39^{\circ} 28^{\prime} 1.17^{\prime \prime} \mathrm{N}$ & $7^{\circ} 12^{\prime} 24.16^{\prime \prime} \mathrm{W}$ & Tejo & $1060 / 2010$ \\
\hline Mp33 & $\mathrm{W} / \mathrm{C} / \mathrm{DS}$ & Alburquerque & 234 & $39^{\circ} 11^{\prime} 0.69^{\prime \prime} \mathrm{N}$ & $7^{\circ} 1^{\prime} 59.03^{\prime \prime} \mathrm{W}$ & Guadiana & $1061 / 2010$ \\
\hline Mp34 & $\mathrm{W}$ & Montalvão, Nisa & 116 & $39^{\circ} 39^{\prime} 50.86^{\prime \prime} \mathrm{N}$ & $7^{\circ} 32^{\prime} 19.27^{\prime \prime} \mathrm{W}$ & Tejo & $1062 / 2010$ \\
\hline Mp36 & W & Bagaúste, Peso da Régua & 50 & $41^{\circ} 9^{\prime} 0.41^{\prime \prime} \mathrm{N}$ & $7^{\circ} 45^{\prime} 2.24^{\prime \prime} \mathrm{W}$ & Douro & $1063 / 2010$ \\
\hline Mp40 & W & Gomes Aires, Almodôvar & 200 & $37^{\circ} 30^{\prime} 58.11^{\prime \prime} \mathrm{N}$ & $8^{\circ} 11^{\prime} 5.17^{\prime \prime} \mathrm{W}$ & - & $1064 / 2010$ \\
\hline Mp41 & $\mathrm{W} / \mathrm{C} / \mathrm{DS}$ & La Codosera & 298 & $39^{\circ} 16^{\prime} 48.08^{\prime \prime} \mathrm{N}$ & $6^{\circ} 52^{\prime} 20.89^{\prime \prime} \mathrm{W}$ & Guadiana & $1065 / 2010$ \\
\hline Mp54 & $\mathrm{W} / \mathrm{C} / \mathrm{DS}$ & Segura, Idanha-a-Nova & 235 & $39^{\circ} 49^{\prime} 11.06^{\prime \prime} \mathrm{N}$ & $6^{\circ} 58^{\prime} 52.99^{\prime \prime} \mathrm{W}$ & Tejo & $1066 / 2010$ \\
\hline Mp55 & $\mathrm{W} / \mathrm{C} / \mathrm{DS}$ & Salvaterra do Extremo, Idanha-a-Nova & 253 & $39^{\circ} 53^{\prime} 37.50^{\prime \prime} \mathrm{N}$ & $6^{\circ} 54^{\prime} 18.38^{\prime \prime} \mathrm{W}$ & Tejo & $1067 / 2010$ \\
\hline Mp59 & $\mathrm{W}$ & Monfortinho, Idanha-a-Nova & 255 & $39^{\circ} 59^{\prime} 9.96^{\prime \prime} \mathrm{N}$ & $6^{\circ} 52^{\prime} 50.23^{\prime \prime} \mathrm{W}$ & Tejo & $069 / 2010$ \\
\hline Mp60 & W & Entradas, Castro Verde & 154 & $37^{\circ} 44^{\prime} 36.51^{\prime \prime} \mathrm{N}$ & $7^{\circ} 58^{\prime} 44.60^{\prime \prime} \mathrm{W}$ & Guadiana & $1070 / 2010$ \\
\hline Mp62 & W & Póvoa, Miranda do Douro & 750 & $41^{\circ} 34^{\prime} 22.71^{\prime \prime} \mathrm{N}$ & $6^{\circ} 19^{\prime} 17.53^{\prime \prime} \mathrm{W}$ & Douro & $1071 / 2010$ \\
\hline Mp63 & W & Escarigo, Figueira de Castelo Rodrigo & 560 & $40^{\circ} 50^{\prime} 34.73^{\prime \prime} \mathrm{N}$ & $6^{\circ} 49^{\prime} 33.62^{\prime \prime} \mathrm{W}$ & Douro & $1072 / 2010$ \\
\hline Mp64 & W & Vilar seco, Miranda do Douro & 725 & $41^{\circ} 31^{\prime} 25.48^{\prime \prime} \mathrm{N}$ & $6^{\circ} 24^{\prime} 5.56^{\prime \prime} \mathrm{W}$ & Douro & $1073 / 2010$ \\
\hline
\end{tabular}

a Sample type: W, wild; C, cultivated; DS, developmental stage. 
by cluster analysis using Numerical Taxonomy Multivariate Analysis System (NTSYS-pc software, version 2.2, Exeter Software, Setauket, New York) (Rohlf, 2000). For cluster analysis, correlation coefficient was selected as a measure of similarity among all accessions, and the Unweighted Pair Group Method with Arithmetical Averages (UPGMA) was used for cluster definition. The degree of correlation was evaluated according to Pestana and Gageiro (2000) and classified as very high (0.9-1), high (0.7-0.89), moderate (0.4-0.69), low (0.2-0.39) and very low $(<0.2)$.

\section{Results and discussion}

\subsection{Morphological studies}

The indumentum of $M$. pulegium includes non-glandular and glandular trichomes scattered all over the vegetative and reproductive organs. The non-glandular trichomes are of three different types: (i) unicellular, with a warty surface, a swollen basal epidermal cell and acute apices (Fig. 2A), which is seen on stems and sepals and on both leaf surfaces, but more abundant on the adaxial surface; (ii) short multicellular, 2-4 cells, uniseriate, warty surface, supported by a cellular pedestal formed by two to five epidermal cells arranged around the base and acute apices, sparse on adaxial leaf surface but common on sepals inner and outer faces (Fig. 2A); (iii) long multicellular, up to 8 cells, with bigger cell dimensions, thin, uniseriate, acute apices, warty surface, always leaned toward the apex and supported by a cellular pedestal formed by two to five epidermal cells, only seen on the petal apex outer face (Fig. 2B). The glandular trichomes belong to two morphologically different types, peltate and capitate, which are considered as the common glandular trichome arrangement in the Lamiaceae family (Werker et al., 1993) and were as well described in Mentha spicata, M. spicata $\times$ suaveolens (Martins, 2002), M. cervina (Rodrigues et al., 2008) and other Lamiaceae species (Ascensão et al., 1999; Corsi and Bottega, 1999; Rodrigues et al., 2006). In M. pulegium peltate trichomes are seen all over both leaf surfaces, dominant on the abaxial surface, on the stem, on the inner and outer surfaces of sepals, and on the outer face apex of petals. They have a short stalk and a smooth large head, with a variable number of secretory cells arranged in one or two circles. Our results show that in M. pulegium 12 cells are probably the most common number in a peltate trichome of mature leaves, usually 4 in the inner circle and 4-8 in the outer (Fig. 2G). That number can reach up to 16 cells in the petals peltate trichomes, usually 4 in the inner circle and 8-12 in the outer. According to Turner et al. (2000) and Martins (2002), the number of cells forming the head disc in peltate trichomes depends on the development stage as well as of the plant species, a mature leaf peltate trichome exhibited 10 disc cells in M. pulegium, 8 in M. piperita (Turner et al., 2000), 12 in M. spicata and $M$. spicata $\times$ suaveolens (Martins, 2002), and 16 in Prostanthera ovalifolia (Gersbach, 2002). Upon maturation, these glandular trichomes are sunken in epidermal depressions and the cuticle of the cells of the secretory head lifts, forming a subcuticular space that encloses secretions. The head dimensions of peltate trichomes are variable, but bigger on the reproductive structures: diameter up to $109 \mu \mathrm{m}( \pm 9 \mu \mathrm{m})$ on the corolla, compared to $88 \mu \mathrm{m}( \pm 10 \mu \mathrm{m})$ on the adaxial leaf surface and $92 \mu \mathrm{m}( \pm 9 \mu \mathrm{m})$ on the abaxial leaf surface. Morphologically well developed peltate glandular trichomes, were also observed on cotyledons (Fig. 2C), as in other Lamiaceae, such as Salvia officinalis and Ocimum basilicum (Croteau et al., 1981; Werker et al., 1993). The peltate trichomes are the only kind of glandular trichomes seen on reproductive structures, occurring along the lower side of the connective tissue, between the two anther lobes (Fig. 2D). This report on the presence of peltate trichomes between the two anther lobes is noteworthy but was also reported for other Lamiaceae species (Ascensão et al., 1995; Rodrigues et al., 2008).

It is within the peltate trichomes that most of the essential oil is believed to be synthesized (Turner et al., 2000). The material secreted by the glandular head cells passes through the apical cell walls and accumulates within a large space formed by the detachment of the cuticle together with the pectin layer of the secretory cell walls. The secretory products remain in this space, giving a spherical shape to each mature peltate trichome. A similar pattern of subcuticular space formation was described in oil glands of other Lamiaceae species (Turner et al., 2000; Werker et al., 1993). Measurements of the glandular secretory head cells and of the subcuticular fillings show that the maximum diameter of the secretory head cells is achieved during an earlier stage of development, and that the increase in total diameter of the peltate glandular trichome is due to further secretion during leaf growth and dependent of the organ in which it is present. Because the accumulation of the secreted material continues during the growth of the organs that bear them, they are considered long-term trichomes (Werker et al., 1993; Werker, 2000 and references there in).

Capitate trichomes are also widespread in Lamiaceae. The types of capitate trichomes found differ in stalk length and head shape and include: (i) capitate type I, with one stalk cell $10 \mu \mathrm{m}( \pm 0.1 \mu \mathrm{m})$ in length, and a round/oval secretory head cell, with a smooth surface (Fig. $2 \mathrm{E}), 27 \mu \mathrm{m}( \pm 2.2 \mu \mathrm{m})$ in length and $21 \mu \mathrm{m}( \pm 1.7 \mu \mathrm{m})$ in diameter at the head, uniformly distributed on both leaf surfaces, calyx and stems; ii) capitate type II, with a lower conical stalk cell, $28 \mu \mathrm{m}( \pm 6 \mu \mathrm{m})$ in length and 1 to 2 elongated neck cells, $12 \mu \mathrm{m}$ $( \pm 0.7 \mu \mathrm{m})$ and a round secretory head cell, with a smooth surface (Fig. $2 \mathrm{~F})$, and $13 \mu \mathrm{m}( \pm 0.1 \mu \mathrm{m})$ in diameter at the head, only on the adaxial petal surface. The capitate trichomes found correspond to the capitate types I and II described by Werker et al. (1985). In capitate glandular trichomes much less material is accumulated in the cell lumen and no rupture of the cuticle was observed.

On fully expanded mature leaves of M. pulegium, the capitate glandular trichomes were densely distributed while the peltate were scattered among them. Similar results were found also in M. pulegium by Karray-Bouraoui et al. (2009) and in both M. spicata and M. spicata $\times$ suaveolens by Martins (2002). The densities observed were: (i) 2.7 and 3.9 peltate trichomes $/ \mathrm{mm}^{2}$ on the adaxial and abaxial leaf surface respectively, (ii) 10 and 13 capitate trichomes $/ \mathrm{mm}^{2}$ on the adaxial and abaxial leaf surface, respectively. These results showed a larger distribution on the abaxial surface, a common feature for several other Lamiaceae species (Ascensão et al., 1995; Rodrigues et al., 2006, 2008; Turner et al., 2000; Werker et al., 1993). Nevertheless, the densities found in $M$. pulegium were the lowest values compared to other studies in $M$. pulegium (Karray-Bouraoui et al., 2009) and other mints (Turner et al., 2000).

\subsection{Histochemical studies}

Data from histochemical tests revealed that the secreted material composition was similar in both leaves and flowers and had a complex nature, containing lipophilic as well as hydrophilic components. The presence of these compounds, although independent of the organ and of its developmental stage, was dependent on the trichome type (Table 3 ). The chemical composition of trichomes secretions seems to be dependent on the type of trichome and be independent of the organ and its development. Secretions from peltate hairs stained positive with Ruthenium Red (pectins), Sudan III (total lipids), Nile Blue (acidic lipids) and Nadi reagent (essential oils), while secretions from capitate hairs only stained positive with Ruthenium Red, Sudan III and Nadi reagent.

The presence of total lipids in secretions of the two types of trichomes and acidic lipids only on peltate trichomes had also been 

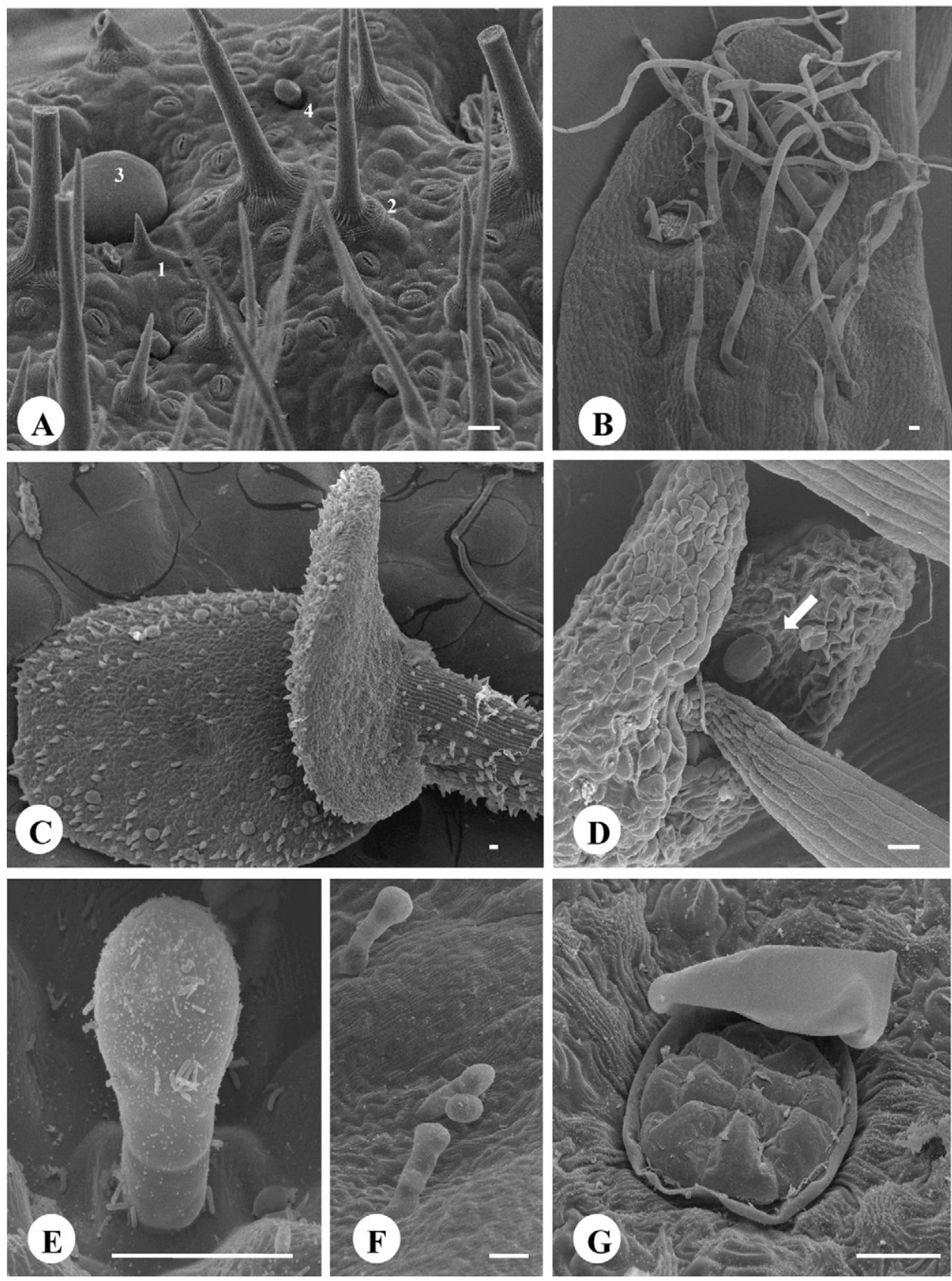

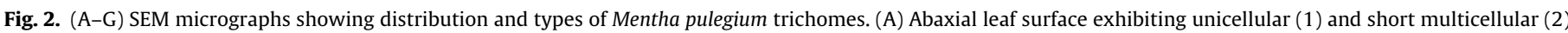

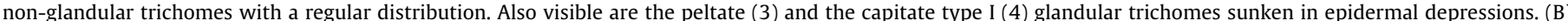

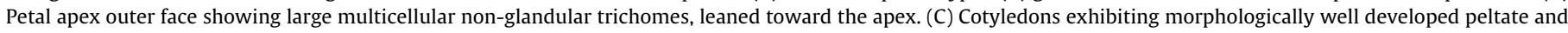

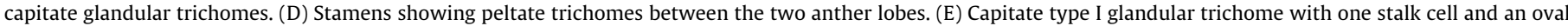

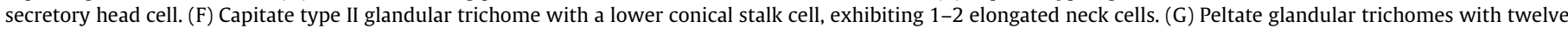
secretory cells, arranged in two circles (bar $=20 \mu \mathrm{m}$ ).

mentioned in previous studies with Tymbra capitata (Rodrigues et al., 2006). The secretions from both trichomes types showed a blue colour with the Nadi reagent, assuming a predominance of essential oils. Similar results also have been verified by Huang et al. (2008) in Lavandula pinnata and also the presence of pectins in the cell walls by Ruthenium Red is referenced in Plectranthus ornatus (Ascensão et al., 1999) and Satureja subspicata (Marin et al., 2010).

\subsection{Essential oil composition}

The essential oil yield, in the 14 wild populations of M. pulegium, collected at full flowering ranged from $0.7 \%$ to $1.6 \%$ (w/d.w.)
(Table 4 ). The average essential oil yield (1.1\%) achieved at the flowering phase is in accordance with some reported oil yields at full flowering for wild $M$. pulegium plants (1.2\%, Hassanpouraghdam et al., 2011), M. arvensis, M. piperita, M. spicata and M. longifolia $(1.7 \%, 1.2 \%, 1.2 \%, 1.0 \%$, respectively, Hussain et al., 2010$)$ but there have been studies reporting twice the yield in M. pulegium (3.8\%, Kokkini et al., 2004; 3.9\%, Cook et al., 2007). Several studies suggest that oil yield is associated with climatic factors; higher temperatures, summer water deficit and higher summer sunshine are factors that seem to favour the overall oil yield (Kokkini et al., 2004; Voirin et al., 1990). Although Portugal has higher temperatures and higher summer sunshine, the typical habitat of this species is not 
Table 3

Histochemistry of the secretions of the glandular trichomes present on the vegetative and reproductive organs of Mentha pulegium.

\begin{tabular}{lllll}
\hline Histochemical test & $\begin{array}{l}\text { Type of com- } \\
\text { pounds/reaction } \\
\text { colour }\end{array}$ & $\begin{array}{l}\text { Peltate } \\
\text { trichomes }\end{array}$ & Capitate trichomes \\
\cline { 3 - 5 } & Total lipids/Red & + & Type I & Type II \\
\hline Sudan III & $\begin{array}{l}\text { Neutral lipids/Pink } \\
\text { Nile Blue }\end{array}$ & - & + & + \\
Acidic lipids/Blue & + & - & - \\
Nadi & Essential oils/Blue & + & - & - \\
Ruthenium Red & $\begin{array}{l}\text { Acidic resins/Red } \\
\text { Pectins/Red }\end{array}$ & - & + & + \\
\hline
\end{tabular}

characterized by summer water deficit, which may explain the low yields found.

Thirty-nine components were identified in the EOs isolated from the M. pulegium populations studied, ranging from 92 to $99 \%$ of the total oil composition. The identified oil components are listed in Table 4 in order of their elution on the DB-1 column, arranged according to the four types of essential oils obtained by agglomerative cluster analysis, with the lowest and the highest percentages found for each component in each volatile oil type.

Mostly quantitative rather than qualitative variation was observed in all the essential oils analyzed. Oxygen-containing monoterpenes (83-98\%) were dominant in all oils, Table 4. Pulegone was the major compound in all of the populations (52-82\%) at full flowering, followed by isomenthone (2-36\%), menthone $(0.1-17 \%)$, and piperitone (1-15\%). Despite some variability among the evaluated populations, cluster analysis (Fig. 3), confirmed a high chemical correlation among all accessions $\left(S_{\text {corr }} \geq 0.9 \%\right)$

Table 4

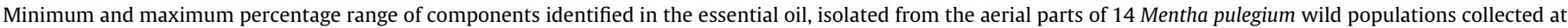
full-flowering phase. For samples grouped on each of the clusters I-II and subclusters a-c, see Fig. 3.

\begin{tabular}{|c|c|c|c|c|c|c|c|c|c|}
\hline \multirow[t]{3}{*}{ Components } & \multirow[t]{3}{*}{ RI } & \multicolumn{2}{|c|}{ Cluster I } & \multicolumn{6}{|c|}{ Cluster II } \\
\hline & & \multirow[t]{2}{*}{ Min } & \multirow[t]{2}{*}{$\operatorname{Max}$} & \multicolumn{2}{|l|}{$\mathrm{a}$} & \multicolumn{2}{|l|}{$\mathrm{b}$} & \multicolumn{2}{|l|}{$\mathrm{c}$} \\
\hline & & & & Min & Max & Min & Max & Min & Max \\
\hline 3-Methyl cyclohexanone & 914 & $\mathrm{t}$ & $\mathrm{t}$ & $\mathrm{t}$ & $\mathrm{t}$ & $\mathrm{t}$ & $\mathrm{t}$ & $\mathrm{t}$ & $\mathrm{t}$ \\
\hline$\alpha$-Thujene & 924 & $\mathrm{t}$ & $\mathrm{t}$ & $\mathrm{t}$ & $\mathrm{t}$ & $\mathrm{t}$ & $\mathrm{t}$ & $\mathrm{t}$ & $\mathrm{t}$ \\
\hline$\alpha$-Pinene & 930 & $\mathrm{t}$ & 0.3 & 0.5 & 0.7 & 0.3 & 0.8 & 0.4 & 0.7 \\
\hline Camphene & 938 & $\mathrm{t}$ & $\mathrm{t}$ & $\mathrm{t}$ & $\mathrm{t}$ & $\mathrm{t}$ & $\mathrm{t}$ & $\mathrm{t}$ & $\mathrm{t}$ \\
\hline Sabinene & 958 & $\mathrm{t}$ & 0.1 & 0.2 & 0.2 & $\mathrm{t}$ & 0.3 & 0.1 & 0.2 \\
\hline 1-Octen-3-ol & 961 & $\mathrm{t}$ & $\mathrm{t}$ & $\mathrm{t}$ & $\mathrm{t}$ & $\mathrm{t}$ & $\mathrm{t}$ & $\mathrm{t}$ & $\mathrm{t}$ \\
\hline$\beta$-Pinene & 963 & 0.3 & 0.4 & 0.4 & 0.5 & 0.2 & 0.6 & 0.3 & 0.5 \\
\hline 3-Octanol & 974 & 1.0 & 1.4 & 1.5 & 1.8 & 1.1 & 1.8 & 1.2 & 2.1 \\
\hline$\beta$-Myrcene & 975 & $\mathrm{t}$ & $\mathrm{t}$ & $\mathrm{t}$ & $\mathrm{t}$ & $\mathrm{t}$ & $\mathrm{t}$ & $\mathrm{t}$ & $\mathrm{t}$ \\
\hline p-Cymene & 1003 & $\mathrm{t}$ & $\mathrm{t}$ & $\mathrm{t}$ & $\mathrm{t}$ & $\mathrm{t}$ & $\mathrm{t}$ & $\mathrm{t}$ & $\mathrm{t}$ \\
\hline 1,8-Cineole & 1005 & $\mathrm{t}$ & $\mathrm{t}$ & 0.3 & 0.3 & $\mathrm{t}$ & 0.4 & $\mathrm{t}$ & 0.2 \\
\hline Limonene & 1009 & $\mathrm{t}$ & $\mathrm{t}$ & 0.3 & 0.4 & 0.2 & 0.5 & 0.3 & 1.2 \\
\hline$\gamma$-Terpinene & 1035 & $\mathrm{t}$ & $\mathrm{t}$ & $\mathrm{t}$ & $\mathrm{t}$ & $\mathrm{t}$ & $\mathrm{t}$ & $\mathrm{t}$ & 0.2 \\
\hline Linalool & 1074 & $\mathrm{t}$ & $\mathrm{t}$ & $\mathrm{t}$ & $\mathrm{t}$ & $\mathrm{t}$ & 0.1 & $\mathrm{t}$ & 0.1 \\
\hline 3-Octanol acetate & 1086 & 0.1 & 0.2 & $\mathrm{t}$ & 0.1 & $\mathrm{t}$ & 0.1 & $\mathrm{t}$ & $\mathrm{t}$ \\
\hline trans-Verbenol & 1114 & $\mathrm{t}$ & $\mathrm{t}$ & $\mathrm{t}$ & $\mathrm{t}$ & $\mathrm{t}$ & $\mathrm{t}$ & $\mathrm{t}$ & $\mathrm{t}$ \\
\hline Menthone & 1120 & 1.5 & 4.2 & 0.9 & 1.1 & 0.1 & 4.0 & 6.5 & 17.0 \\
\hline Isomenthone & 1126 & 28.6 & 36.0 & 17.7 & 22.7 & 8.1 & 22.7 & 1.9 & 10.8 \\
\hline Menthofuran & 1134 & $\mathrm{t}$ & $\mathrm{t}$ & $\mathrm{t}$ & $\mathrm{t}$ & $\mathrm{t}$ & $\mathrm{t}$ & $\mathrm{t}$ & $\mathrm{t}$ \\
\hline cis-Isopulegone & 1134 & 0.7 & 0.7 & 0.7 & 0.8 & 0.8 & 1.2 & 0.8 & 0.9 \\
\hline Menthol & 1148 & $\mathrm{t}$ & $\mathrm{t}$ & $\mathrm{t}$ & $\mathrm{t}$ & $\mathrm{t}$ & $\mathrm{t}$ & $\mathrm{t}$ & $\mathrm{t}$ \\
\hline Terpinen-4-ol & 1148 & $\mathrm{t}$ & $\mathrm{t}$ & $\mathrm{t}$ & $\mathrm{t}$ & $\mathrm{t}$ & 0.1 & $\mathrm{t}$ & $\mathrm{t}$ \\
\hline$\alpha$-Terpineol & 1159 & $\mathrm{t}$ & 0.2 & $\mathrm{t}$ & 0.2 & $\mathrm{t}$ & 0.2 & $\mathrm{t}$ & 0.2 \\
\hline Myrtenol & 1168 & $\mathrm{t}$ & $\mathrm{t}$ & $\mathrm{t}$ & $\mathrm{t}$ & $\mathrm{t}$ & 0.1 & $\mathrm{t}$ & 0.1 \\
\hline Pulegone & 1210 & 52.0 & 55.5 & 60.3 & 61.4 & 61.4 & 81.8 & 57.0 & 69.8 \\
\hline Piperitone epoxide & 1210 & $\mathrm{t}$ & $\mathrm{t}$ & $\mathrm{t}$ & $\mathrm{t}$ & $\mathrm{t}$ & $\mathrm{t}$ & $\mathrm{t}$ & $\mathrm{t}$ \\
\hline Piperitone & 1211 & 1.0 & 3.1 & 1.1 & 2.2 & $\mathrm{t}$ & 1.1 & 0.5 & 2.2 \\
\hline Menthyl acetate & 1278 & $\mathrm{t}$ & $\mathrm{t}$ & $\mathrm{t}$ & $\mathrm{t}$ & $\mathrm{t}$ & $\mathrm{t}$ & $\mathrm{t}$ & $\mathrm{t}$ \\
\hline Isomenthyl acetate & 1288 & $\mathrm{t}$ & $\mathrm{t}$ & $\mathrm{t}$ & $\mathrm{t}$ & $\mathrm{t}$ & $\mathrm{t}$ & $\mathrm{t}$ & $\mathrm{t}$ \\
\hline Piperitenone & 1289 & 3.0 & 6.6 & 6.8 & 13.1 & 0.6 & 6.8 & 5.0 & 14.9 \\
\hline Nepetalactone & 1291 & $\mathrm{t}$ & $\mathrm{t}$ & $\mathrm{t}$ & $\mathrm{t}$ & $\mathrm{t}$ & $\mathrm{t}$ & $\mathrm{t}$ & $\mathrm{t}$ \\
\hline Piperitenone oxide & 1315 & $\mathrm{t}$ & $\mathrm{t}$ & $\mathrm{t}$ & $\mathrm{t}$ & $\mathrm{t}$ & $\mathrm{t}$ & $\mathrm{t}$ & 0.3 \\
\hline$\beta$-Bourbonene & 1379 & $\mathrm{t}$ & $\mathrm{t}$ & $\mathrm{t}$ & 1.1 & $\mathrm{t}$ & 5.7 & $\mathrm{t}$ & 1.1 \\
\hline$\beta$-Caryophyllene & 1414 & $\mathrm{t}$ & $\mathrm{t}$ & $\mathrm{t}$ & $\mathrm{t}$ & $\mathrm{t}$ & 0.1 & $\mathrm{t}$ & 0.1 \\
\hline$\alpha$-Humulene & 1447 & $\mathrm{t}$ & $\mathrm{t}$ & $\mathrm{t}$ & $\mathrm{t}$ & $\mathrm{t}$ & $\mathrm{t}$ & $\mathrm{t}$ & $\mathrm{t}$ \\
\hline 2-Methoxy-6-methylacetophenone ${ }^{\mathrm{a}}$ & 1447 & $\mathrm{t}$ & $\mathrm{t}$ & $\mathrm{t}$ & $\mathrm{t}$ & $\mathrm{t}$ & $\mathrm{t}$ & $\mathrm{t}$ & $\mathrm{t}$ \\
\hline$\beta$-Caryophyllene oxide & 1561 & $\mathrm{t}$ & $\mathrm{t}$ & $\mathrm{t}$ & $\mathrm{t}$ & $\mathrm{t}$ & $\mathrm{t}$ & $\mathrm{t}$ & $\mathrm{t}$ \\
\hline Humulene epoxide & 1580 & $\mathrm{t}$ & $\mathrm{t}$ & $\mathrm{t}$ & $\mathrm{t}$ & $\mathrm{t}$ & $\mathrm{t}$ & $\mathrm{t}$ & $\mathrm{t}$ \\
\hline 2-Methyl jasmonate & 1634 & $\mathrm{t}$ & $\mathrm{t}$ & $\mathrm{t}$ & $\mathrm{t}$ & $\mathrm{t}$ & $\mathrm{t}$ & $\mathrm{t}$ & $\mathrm{t}$ \\
\hline \% Identification & & 97.4 & 99.5 & 98.0 & 99.3 & 92.1 & 98.9 & 95.0 & 99.0 \\
\hline \multicolumn{10}{|l|}{ Grouped components } \\
\hline Monoterpene hydrocarbons & & 0.5 & 0.6 & 1.5 & 1.7 & 0.7 & 2.2 & 1.1 & 2.6 \\
\hline Oxygen-containing monoterpenes & & 95.4 & 97.7 & 94.4 & 95.2 & 82.5 & 96.9 & 90.4 & 95.7 \\
\hline Sesquiterpene hydrocarbons & & $\mathrm{t}$ & $\mathrm{t}$ & $\mathrm{t}$ & 1.1 & $\mathrm{t}$ & 5.7 & $\mathrm{t}$ & 1.2 \\
\hline Oxygen-containing sesquiterpenes & & $\mathrm{t}$ & $\mathrm{t}$ & $\mathrm{t}$ & $\mathrm{t}$ & $\mathrm{t}$ & $\mathrm{t}$ & $\mathrm{t}$ & $\mathrm{t}$ \\
\hline Others $^{\mathrm{b}}$ & & 1.2 & 1.5 & 1.5 & 1.9 & 1.1 & 1.9 & 1.2 & 2.1 \\
\hline Oil yield (w/d.w.) & & 0.7 & 1.2 & 1.1 & 1.1 & 0.9 & 1.6 & 0.7 & 1.1 \\
\hline
\end{tabular}

$\mathrm{RI}$, retention index relatite to $\mathrm{C}_{9}-\mathrm{C}_{17} n$-alkanes on the DB-1 column; t, traces $(<0.05 \%)$.

a Identification based on mass spectra only.

b Components that do not fit on the classification of terpenes or phenylpropanoids and which are mainly non aromatic alcohols, ketones and alkenes. 


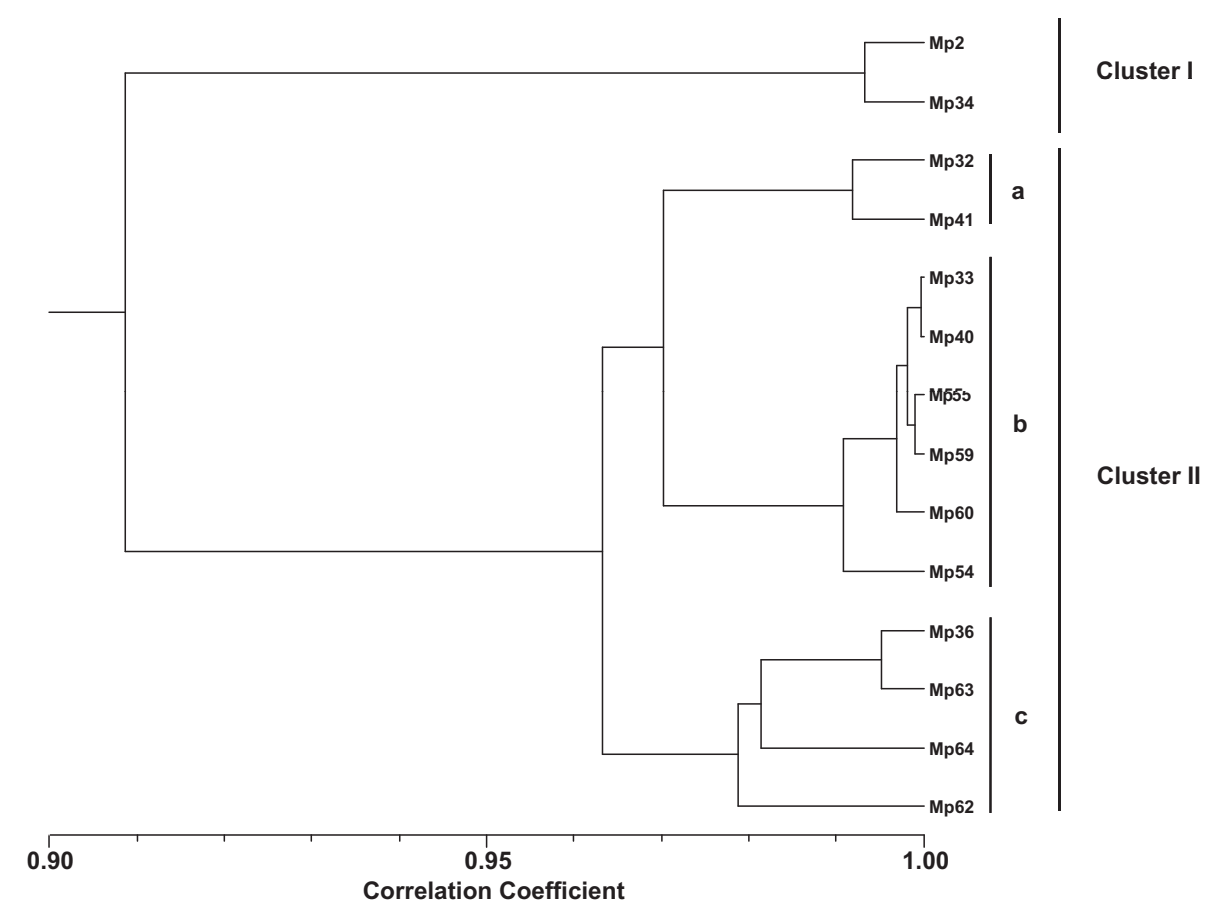

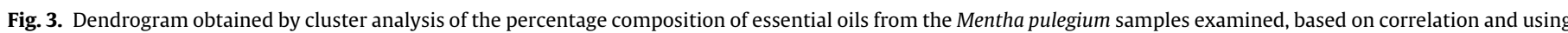
the unweighted pair-group method with arithmetic average (UPGMA). For abbreviations, see Table 2.

even though defining two clusters, and 3 sub-clusters, in total. Although some clusters overlapped, others were clearly separated and grouped populations according to their geographical collection site (Fig. 1). The main differences between the two clusters were the pulegone $(\leq 55 \%)$ and isomenthone $(>28 \%)$ relative amounts in cluster I. Menthone relative amount $(>6 \%)$ separated sub-cluster IIc, and isomenthone relative amount $(>17 \%)$ sub-cluster IIa, from the other EO in sub-cluster IIb.

A literature assessment (Table 1) showed that in pennyroyal pulegone-type essential oils, pulegone usually ranges from 60 to $90 \%$. In Portugal, a recent study on one M. pulegium population described menthone (36\%) and pulegone (23\%) as the main essential oil components (Teixeira et al., 2012). In the present study, all the essential oils belong to the pulegone chemotype, supporting the results of Monteiro et al. (2007b) and Lopes et al. (2010), on nineteen cultivated Portuguese populations collected during the flowering phase; Reis-Vasco et al. (1999) in one population collected in Sintra, and Mata et al. (2007), in one sample bought in a local market in Alentejo Region. M. pulegium studied oils showed a different behaviour from the oils of most of the other mints, since the existence of different chemotypes is a common feature in Mentha species and hybrids (Kokkini and Vokou, 1989).

In plant developmental terms, the essential oil yield had a different behaviour according to the growing conditions. For wild growing populations, the essential oil yield increased from the vegetative stage (mean value $0.5 \% \mathrm{w} / \mathrm{d} . \mathrm{w}$.) until full flowering, June and July (mean value $1.1 \% \mathrm{w} / \mathrm{d} . \mathrm{w}$ ). Opposite behaviour was observed in the cultivated ones $(1.9 \% \mathrm{w} / \mathrm{d} . \mathrm{w}$ at the vegetative stage for $1.1 \%$ $\mathrm{w} /$ d.w at the flowering stage). In general, wild growing populations showed a lower oil yield compared with the cultivated ones. The analysis of the main EO constituents revealed that pulegone remained the major constituent, along the life cycle of the plant, for both growing conditions, although the behaviour of the main components was slightly different (Fig. 4).

In the EO isolated from cultivated populations, pulegone relative amount increased from the vegetative until the full-flowering phase and then it started to decrease towards the end of the cycle.
In the EO isolated from wild growing populations, the relative amount in pulegone increased until the vegetative phase and then decreased anticipating the pre-flowering phase. Towards the full flowering the pulegone relative amount suffered a new increase. These changes were followed by changes in the isomenthone and menthone relative amounts, whenever the pulegone decreased, the isomenthone and menthone tended to increase. In the EO isolated from cultivated populations, menthone and isomenthone reached their maximum at the vegetative phase and decreased towards the end of the cycle (Fig. 4). These variations may be due to the influence of the developmental stage and environmental conditions on the regulation of the biosynthesis of essential oil, since it is

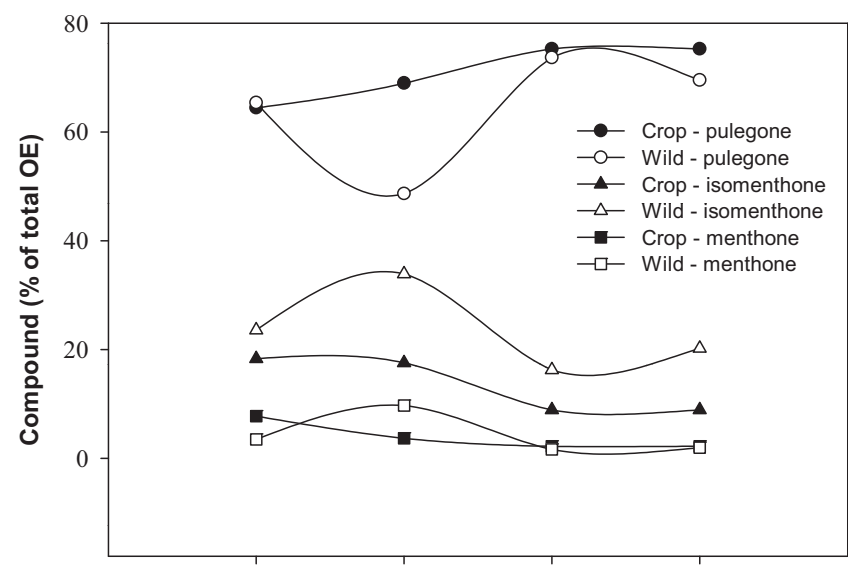

Vegetative Pre-flowering Flowering Full-Flowering

Fig. 4. Time-course study of the main components of the Mentha pulegium essential oils isolated in wild (open symbols) and cultivated (closed symbols) growing conditions at different developmental stages. Given the extended period of flowering, two sampling points, one month apart, were considered at this developmental stage. Flowering corresponding to $50 \%$ of the plants blooming and Full-flowering when $100 \%$ of the plants where blooming. The values are the mean values from 6 populations. 
known that the biosynthesis of the essential oils is affected by physiological variations (i.e. organ and leaf position), environmental conditions (i.e. harvest date and planting time), geographic variations and genetic factors and evolution (Figueiredo et al., 2008). It can be hypothesized that wild growing plants are subject to more stress variables (overgrazing, human disruption, water deficit), and that under these conditions they prioritize the metabolism, which results in the reduction of pulegone, favouring isomenthone and menthone. In Mentha $\mathrm{x}$ piperita leaves, pulegone is reduced by a NADPH-pulegone reductase to yield (-)-menthone and (+)isomenthone, in an approximately 10:1 ratio (Davis et al., 2005). In this study menthone was also clearly dominant, but in a higher ratio, except for the wild growing populations in the pre-flowering phase. The change observed in the present study, between the relative amounts of menthone and isomenthone trough the life cycle may reflect some degree of substrate specificity or other environmental and/or physiological condition.

\section{Conclusions}

M. pulegium aerial parts showed different types of glandular and non glandular trichomes similar to those previously described for Lamiaceae. Histochemistry studies revealed the presence of pectins in the cell walls and total lipids, acidic lipids and essential oils in the secretions of the peltate and capitate glandular trichomes. The attained essential oil yield for this species was in accordance with those reported in previous studies. M. pulegium populations studied showed a pulegone chemotype essential oil, although the menthone and isomenthone relative amounts could further differentiate these oils. The evaluation of the effect of the developmental stage and growing conditions on essential oil composition showed mostly quantitative rather than qualitative variations, supporting the view that both factors together can influence the regulation of the biosynthesis of essential oils. Our results also showed that cultivation only seems to affect the essential oil yield, increasing its content, not affecting the essential oil composition that seems to be more stable and uniform. These are features that turn this species into interesting products for cultivation and commercialization.

\section{Acknowledgements}

Leandra Rodrigues is grateful to the Foundation for Science and Technology (FCT) for the PhD grant SFRH/BD/38143/2008. This study was partially funded by the Portuguese Ministry of Agriculture and Rural Fisheries Development, Agro Program, Project $n^{\circ} 522$.

\section{References}

Aghel, N., Yamni, Y., Hajiakhoondi, A., Pourmortazavi, S.M., 2004. Supercritical carbon dioxide extraction of Mentha pulegium L. essential oil. Talanta 62, 407-411.

Agnihotri, V.K., Agarwal, S.G., Dhar, P.L., Thapp, R.K., Baleshwar, Kapahi, B.K., Saxena, R.K., Qazi, G.N., 2005. Essential oil composition of Mentha pulegium L. growing wild in the north-western Himalayas India. Flavour Frag. J. 20, 607-610.

Anderson, I.B., Mullen, W.H., Meeker, J.E., Khojasteh-Bakht, S.C., Oisi, S., Nelson, S.D., Blanc, P.D., 1996. Pennyroyal toxicity: measurements of toxic metabolite levels in two cases and review of the literature. Ann. Intern. Med. 124, 726-734.

Ascensão, L., Marques, N., Pais, M.S., 1995. Glandular trichomes on vegetative and reproductive organs of Leonotis leonurus (Lamiaceae). Ann. Bot. 75, 619-626.

Ascensão, L., Mota, L., Castro, M.M., 1999. Glandular trichomes on the leaves and flowers of Plectranthus ornatus: morphology, distribution and histochemistry. Ann. Bot. 84, 437-447.

Beghidja, N., Bouslimani, N., Benayache, F., Benayache, S., Chalchat, J.C., 2007. Composition of the oils from Mentha pulegium grown in different areas of the east of Algeria. Chem. Nat. Compd. 43, 481-483.

Barceloux, D.G., 2008. Pennyroyal and Pulegone (Mentha pulegium L.). In: Medical Toxicology of Natural Substances: Foods, Fungi, Medicinal Herbs, Plants and Venomous Animals. John Wiley \& Sons, Hoboken, NJ, pp. 563-567.

Chalchat, J.C., Gorunovlc, M.S., Maksimovlc, Z.A., Petrovlc, S.D., 2000. Essential oil of wild growing Mentha pulegium L from Yugoslavia. J. Essent. Oil Res. 12, 598-600.
Cook, C., Maloupa, E., Kokkini, S., Lanaras, T., 2007. Differences between the inflorescence, leaf and stem essential oils of wild Mentha pulegium plants from Zakynthos, Greece. J. Essent. Oil Res. 19, 239-243.

Corsi, G., Bottega, S., 1999. Glandular hairs of Salvia officinalis: new data on morphology, localization and histochemistry in relation to function. Ann. Bot. 84, 657-664.

Council of Europe, 2007. European Pharmacopoeia, 6th ed. Strasbourg, pp. 251-252.

Croteau, R., Felton, M., Karp, F., Kjonaas, R., 1981. Relationship of camphor biosynthesis to leaf development in sage (Salvia officinalis). Plant Physiol. 67, 820-824.

David, R., Carde, J.P., 1964. Coloration différentielle des pseudophylles de Pin maritime au moyen du réactif de Nadi. Cr. Acad. Sci. II 258, 1338-1340.

Davis, E.M., Ringer, K.L., McConkey, M.E., Croteau, R., 2005. Monoterpene metabolism. Cloning, expression, and characterization of menthone reductases from peppermint. Plant Physiol. 137, 873-881.

EEC, 1988. Council Directive 88/388/EEC of 21 June 1988 on the approximation of the laws of the Member States relating to flavourings for use in foodstuffs and to source materials for their production, Official Journal of the European Communities, 15.7.1988, L184/61-41167.

Evans, W.C., 1996. Trease and Evans Pharmacognosy, 14th ed. Saunders Company Ltd., London.

Figueiredo, A.C., Barroso, J.G., Pedro, L.G., Scheffer, J.J.C., 2008. Factors affecting secondary metabolite production in plants: volatile components and essential oils. Flavour Frag. J. 23, 213-226.

Gersbach, P.V., 2002. The essential oil secretory structures of Prostanthera ovalifolia (Lamiaceae). Ann. Bot. 89, 255-260.

Hajlaoui, H., Snoussi, M., Noumi, E., Zanetti, S., Ksouri, R., Bakhrouf, A., 2010. Chemical composition, antioxidant and antibacterial activities of the essential oils of five Tunisian aromatic plants. Ital. J. Food Sci. 22, 320-329.

Hassanpouraghdam, M.B., Akhgari, A.B., Aazami, M.A., Emarat-Pardaz, J., 2011. New Menthone Type of Mentha pulegium L. Volatile Oil from Northwest Iran. Czech J. Food Sci. 29, 285-290.

Huang, S.S., Kirchoff, B.K., Liao, J.P., 2008. The Capitate and Peltate Glandular Trichomes of Lavandula pinnata L. (Lamiaceae): histochemistry, ultrastructure and secretion. J. Torrey Bot. Soc. 135, 155-167.

Hussain, A.I., Anwar, F., Nigam, P.S., Ashrafd, M., Gilanif, A.H., 2010. Seasonal variation in content, chemical composition and antimicrobial and cytotoxic activities of essential oils from four Mentha species. J. Sci. Food Agric. 90, 1827-1836.

Jensen, W.A., 1962. Botanical Histochemistry; Principles and Practice. Freeman, San Francisco, CA.

Johansen, D.A., 1940. Plant Microtechnique. McGraw-Hill, New York.

Karray-Bouraoui, N., Rabhi, M., Neffati, M., Baldan, B., Ranieri, A., Brahim, M., Lachaâl, M., Smaoui, A., 2009. Salt effect on yield and composition of shoot essential oil and trichome morphology and density on leaves of Mentha pulegium. Ind. Crop Prod. 30, 338-343.

Kokkini, S., Vokou, D., 1989. Mentha spicata (Lamiaceae) chemotypes growing wild in Greece. Econ. Bot. 43, 192-202.

Kokkini, S., Hanlidou, E., Karousou, R., 2004. Clinal Variation of Mentha pulegium essential oils along the climatic gradient of Greece. J. Essent. Oil Res. 16, 588-593.

Lopes, V.R., Barata, A.M., Rocha, F., Pedro, L.G., Barroso, J.G., Figueiredo, A.C., 2010. Morphological and chemical variability assessment from Portuguese Mentha pulegium L. (pennyroyal) accessions. In: Proceedings of the VIII International Ethnobotany Symposium, pp. 573-583.

Lorenzo, D., Paz, D., Dellacassa, E., Davies, P., Vila, R., Canigueral, S., 2002. Essential oils of Mentha pulegium and Mentha rotundifolia from Uruguay. Braz. Arch. Biol. Technol. 45, 1-6.

Mahboubi, M., Haghi, G., 2008. Antimicrobial activity and chemical composition of Mentha pulegium L. essential oil. J. Ethnopharmacol. 119, 325-327.

Marin, M., Jasnic, N., Lakusic, D., Duletic-Lausevic, S., Ascensão, L., 2010. The micromorphological Histochemical and Confocal Analysis of Satureja subspicata Bartl. Ex Vis. Glandular Trichomes. Arch. Biol. Sci. 62, 1143-1149.

Maroto-Diaz, M.C., Castillo, N., Castro-Vazquez, L., Gonzalez-Vinas, M.A., PerezCoello, M., 2007. Volatile composition and olfactory profile of pennyroyal (Mentha pulegium L.) plants. Flavour Frag. J. 22, 114-118.

Martins, M.B.G., 2002. Estudos de microscopia óptica e de microscopia eletrônica de verredura em folhas de Menta spicata e de Menta spicata $\times$ suaveolens (Lamiaceae). Bragantia. Campinas 61, 205-218.

Mata, A.T., Proença, C., Ferreira, A.R., Serralheiro, M.L.M., Nogueira, J.M.F., Araújo, M.E.M., 2007. Antioxidant and antiacetylcholinesterase activities of five plants used as Portuguese food spices. Food Chem. 103, 778-786.

Mimica-Dukic, N., Bozin, B., 2008. Mentha L. species (Lamiaceae) as promising sources of bioactive secondary metabolites. Curr. Pharm. Des. 14, 3141-3150.

Mkaddem, M., Bousaid, M., Ben Fadhel, N., 2007. Variability of volatiles in Tunisian Mentha pulegium L. (Lamiaceae). J. Essent. Oil Res. 19, 211-215.

Monteiro, A., Póvoa, O., Marinho, S., Rodrigues, L., Monteiro, P., 2007a. Mentha pulegium e Mentha cervina Os Poejos na boa Cozinha Portuguesa. ISA Press, Lisboa.

Monteiro, P., Póvoa, O., Rodrigues, L., Monteiro, A., Martins, M.M., Figueiredo, A.C., 2007b. Quantificação e caracterização do óleo essencial de Mentha pulegium. Actas do II Colóquio Nacional de Plantas Aromáticas e Medicinais, Associação Portuguesa de Horticultura, 230-236.

Mucciarelli, M., Camusso, W., Bertea, C.M., Bossi, S., Maffei, M., 2001. Effect of $(+)$-pulegone and other oil components of Mentha $\times$ piperita on cucumber respiration. Phytochemistry 57, 91-98.

Pestana, M.H., Gageiro, J.N., 2000. Análise de Dados para Ciências Sociais. A complementaridade do SPSS. Edições Sílabo, Lisbon. 
Póvoa, O., Farinha, N., Marinho, S., Nunes, P., Godinho, D., Mata, F., Rodrigues, L., Monteiro, A., 2006. Pennyroyal (Mentha pulegium) and Hart's Pennyroyal (Mentha cervina) biodiversity in Alentejo, Portugal. Acta Hortic. 723, 91-97.

Reis-Vasco, E.M.C., Coelho, J.A.P., Palavra, A.M.F., 1999. Comparison of pennyroyal oils obtained by supercritical $\mathrm{CO}_{2}$ extraction and hydrodistillation. Flavour Frag. J. $14,156-160$.

Rodrigues, L.S., Monteiro, P., Póvoa, O., Teixeira, G., Vasconcelos, T., Moldão, M., Monteiro, A., 2006. Biodiversity studies on Portuguese Thymbra capitata. Acta Hortic. $723,127-132$

Rodrigues, L., Monteiro, P., Póvoa, O., Teixeira, G., Moldão, M., Figueiredo, A.C., Monteiro, A., 2008. Morphology of secretory structures and essential oil composition in Mentha cervina L. from Portugal. Flavour Frag. J. 23, 340-347.

Rohlf, F.J., 2000. NTSYS-pc: Numerical Taxonomy and Multivariate Analysis System, Version 2.1 Exeter Software. Applied Biostatistics, New York.

Sarikurkcu, C., Eryigit, F., Cengiz, M., Tepe, B., Cakir, A., 2012. Screening of the antioxidant activity of the essential oil and methanol extract of Mentha pulegium L. from Turkey. Spectrosc. Lett. 45, 352-358.

Stengele, M., Stahl-Biskup, E., 1993. Seasonal variation in the essential oil of European pennyroyal (Mentha pulegium L.). Acta Hortic. 344, 41-51.

Stoyanova, A., Georgiev, E., Kula, J., Majda, T., 2005. Chemical composition of the essential oil of Menthapulegium L. from Bulgaria. J. Essent. Oil Res. 17, 475-476.
Teixeira, B., Marquesa, A., Ramosa, C., Batista, I., Serrano, C., Matos, O., Neng, N. Nogueira, J.M.F., Saraiva, J.A., Nunes, M.L., 2012. European pennyroyal (Mentha pulegium) from Portugal: chemical composition of essential oil and antioxidant and antimicrobial properties of extracts and essential oil. Ind. Crop. Prod. 36, 81-87.

Turner, G.W., Gershenzon, J., Croteau, R.B., 2000. Distribution of peltate glandular trichomes on developing leaves of peppermint. Plant Physiol. 124, 655-664.

Tutin, T.J., Heywood, V.H., Burgess, N.A., Moore, D.M., Valentine, D.H., Walters, S.M., Webb, D.A., 1972. Flora Europeae, vol. III, CLI. Labiatae. University Press, Cambridge.

Voirin, B., Brun, N., Bayet, C., 1990. Effect of day length on the monoterpene composition of leaves of Mentha $\times$ piperita. Phytochemistry 29, 749-755.

Werker, E., 2000. Trichome diversity and development. Adv. Bot. Res. 31, 1-35.

Werker, E., Putievsky, E., Ravid, U., Dudai, N., Katzir, I., 1993. Glandular hairs and essential oil in developing leaves of Ocimum basilicum L. (Lamiaceae). Ann. Bot. 71, 43-50.

Werker, E., Ravid, U., Putievsky, E., 1985. Structure of glandular hairs and identification of the main components of their secreted material in some species of the Labiatae. Isr. J. Bot. 34, 31-45. 